\section{Myocardial infarction at the patient with parathyroid adenoma}

\author{
Zivana Slovic ${ }^{1}$, Katarina Vitosevic ${ }^{1}$, Snezana Jancic ${ }^{2}$, \\ Stevan Matic ${ }^{3}$, Milos S. Todorovic ${ }^{1}$ \\ ${ }^{1}$ University of Kragujevac, Serbia, Faculty of Medical Sciences, \\ Department of Forensic Medicine \\ ${ }^{2}$ University of Kragujevac, Serbia, Faculty of Medical Sciences, \\ Department of Pathology \\ ${ }^{3}$ Clinical center, Kragujevac, Serbia, Department of Pathology \\ ${ }^{4}$ Clinical center, Kragujevac, Serbia, Department of Forensic Medicine \\ and Toxicology
}

\section{Abstract}

Parathyroid gland adenoma belongs to the benign tumor group and is the commonest originator of the primary hyperthyroidism which emerges owing to the both increased and uncontrolled secretion of parathyroid hormone due to the one or more parathyroid glands hyperfunction. The paper outlines the woman case, who was at the prison sentence enduring, and as a result of the supraventricular tachycardia and hemodynamic instability she was hospitalized at the Clinical centre, Kragujevac. The obduction diagnosed atherosclerosis of severe degree, left ventricle hypertrophy, nephrolithiasis, whereas the organs' cut-outs pathohistological examination showed parathyroid gland adenoma. The cause of death of the particular patient was the myocardial infarction. Parathyroid adenoma of the patient was not detected in time because of the state of neglect and her way of life. The primary hyperthyroidism has significantly speeded up the myocardial damage and the blood vessel atherosclerotic changes.

Key words: myocardial infarction, parathyroid adenoma, primary hyperthyroidism, autopsy

\section{Infarkt miokarda kod pacijentkinje sa adenomom paratiroidne žlezde}

\author{
Živana Slović1 ${ }^{\text {, Katarina Vitošević }}{ }^{\text {, Snežana Jančić }}{ }^{\text {, }}$ \\ Stevan Matić ${ }^{3}$, Miloš S. Todorović1 \\ ${ }^{1}$ Univerzitet u Kragujevcu, Srbija, Fakultet Medicinskih Nauka, \\ Katedra za Sudsku medicinu \\ ${ }^{2}$ Univerzitet u Kragujevcu, Srbija, Fakultet Medicinskih Nauka, \\ Katedra za Patologiju \\ ${ }^{3}$ Klinički centar Kragujevac, Srbija, Služba za Patologiju \\ ${ }^{4}$ Klinički centar Kragujevac, Srbija, Služba za Sudsku medicine \\ toksikologiju
}

\section{Apstrakt}

Adenom paratiroidne žlezde spada u grupu benignih tumora i najčešći je uzročnik primarnog hiperparatireoidizma, koji nastaje usled povećanog i nekontrolisanog lučenja paratireoidnog hormona zbog hiperfunkcije jedne ili više paratireoidnih žlezda. U radu je prikazan slučaj žene, koja je bila na izdržavanju zatvorske kazne, pa je zbog pojave supraventrikularne tahikardije $\mathrm{i}$ hemodinamske nestabilnosti hospitalizovana u Kliničkom centru Kragujevac. Obdukcijom je konstatovana ateroskleroza teškog stepena, hipertrofija leve komore, nefrolitijaza, a patohistološkim pregledom isečaka organa adenoma paratiroidne žlezde. Uzrok smrti ove pacijentkinje bio je infarct miokarda. Adenom paratiroidne žlezde pacijentkinje nije dijagnostikovan na vreme zbog zapuštenosti i načina njenog života. Primarni hiperparatireoidizam je u značajnoj meri ubrzao oštećenje miokarda i aterosklerozne promene krvnih sudova.

Ključne reči: infarkt miokarda, adenom paratiroidne žlezde, primarni hiperparatireoidizam, obdukcija

\title{
Introduction
}

Parathyroid adenoma belongs to the group of benign tumors and is characterized by the hyper function of one or more parathyroid glands causing hyperparathyroidism ${ }^{1}$. In $85 \%$ of the cases a single benign adenoma causes primary hyperparathyroidism (pHPT). The agents of pHPT can also be multiple adenomas and parathyroid glands hyperplasia, but in a significantly smaller percent (around 15\%), while carcinomas are extremely rare (around $1 \%)^{2,3}$.The most important clinical manifestation of pHPT is the increase of serum concentration of calcium, which occurs due to increased bone absorption, decreased urinary calcium elimination and increased absorption in the intestines ${ }^{3,4}$. Hyperparathyroidism is one of the risks for the onset of cardiovascular diseases because these patients more often have hypertrophy of the left ventricle, and atherosclerotic alterations of blood vessels and valves ${ }^{5,6}$. 


\section{Case report}

\section{Admission report:}

A female patientwas admitted to Clinical Center Kragujevac, as an emergency, due to a pain in the chest, dizziness and the sensation of a rapid heartbeat. The patient served prison sentence where her condition deteriorated. During admission she was alert, disoriented, with an altered mental status, dyspneic, afebrile, pale and dehydrated. Abnormal heart rhythm was electrocardiographically verified as supraventricular tachycardia with a frequency of $165 / \mathrm{min}$, and blood pressure was $65 / 40 \mathrm{mmHg}$. Ultrasound (US) of abdomen showed damage in kidneys with multiple calculi on both sides. Despite cardiopulmonary reanimation, cardiopulmonary arrest soon ensued.

\section{Autopsy report:}

An order was requested for conducting forensic and clinical autopsy because of violent death suspicion in prison conditions.

Exterior report indicates that skeleton and muscles are badly developed, she is emaciated and neglected. Rigor mortis is moderately developed in all joints, and livor mortis is moderately developed with a usual purplish grey color. A few tattoos in the area of upper extremities are noticed upon exterior examination.

Neck's interior report indicates enlarged parathyroid gland on the left side, with a diameter of $35 \times 30 \times 30$ $\mathrm{mm}$, clearly separated from the surrounding tissue of thyroid gland, which is glassy, less clearly built and yellowish brown on section.

Lungs tissue is moderately airy and elastic, with a flat sectionfrom which foamy greyish contents spontaneously overflow, and upon pressure they pour out from both bronchi and bronchioles.

The heart is $11.5 \times 9.5 \mathrm{~cm}$ big and $390 \mathrm{~g}$ heavy, with moderately expressed fat tissue. Left ventricle wall's thickness is up to $18 \mathrm{~mm}$, and the right ventricle wall is up to $4 \mathrm{~mm}$. Heart muscle is flabby, less clearly built on section, interspersed with whitish strips of ligaments. Coronary arteries have inflexible walls with separate and merged, up to $5 \mathrm{~mm}$ thick, atherosclerotic plaques. On the left descending coronary artery, atherosclerotic plaque almost completely closes blood vessel lumen, with fresh bleeding present in the plaque.

Kidneys are $280 \mathrm{~g}$ heavy, with an uneven fine-grained surface, unclear and muddy texture, and there are pus and calculi in renal pelvises.

\section{Pathohistological report:}

Pathohistological examination of organ segments diagnosed parathyroid adenoma (Figure 1). On hypertrophic heart muscle fibers there is a calcification of thickened arterial blood vessels (Figure 2). There is nephrocalcinosis in kidneys, with clear calcification of basal membranes of renal ducts (Figure 3). Alveolar basal membrane is calcified on pulmonary tissue, and alveolar lumina are filled with inflammatory infiltrate and hemosiderophages (Figure 4). 


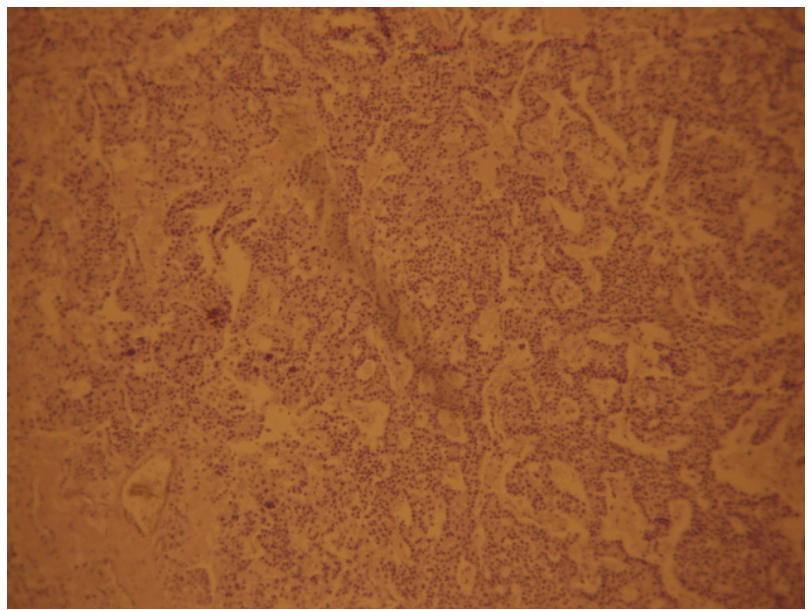

Figure 1

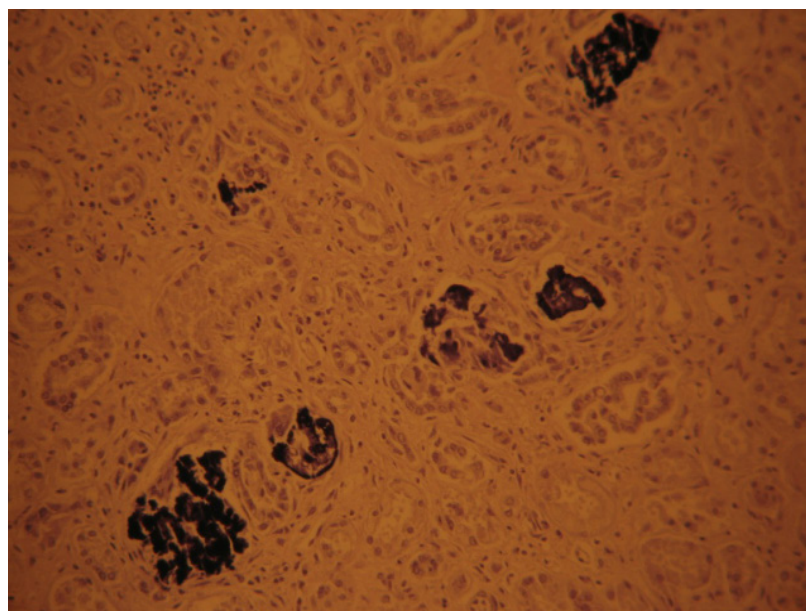

Figure 3

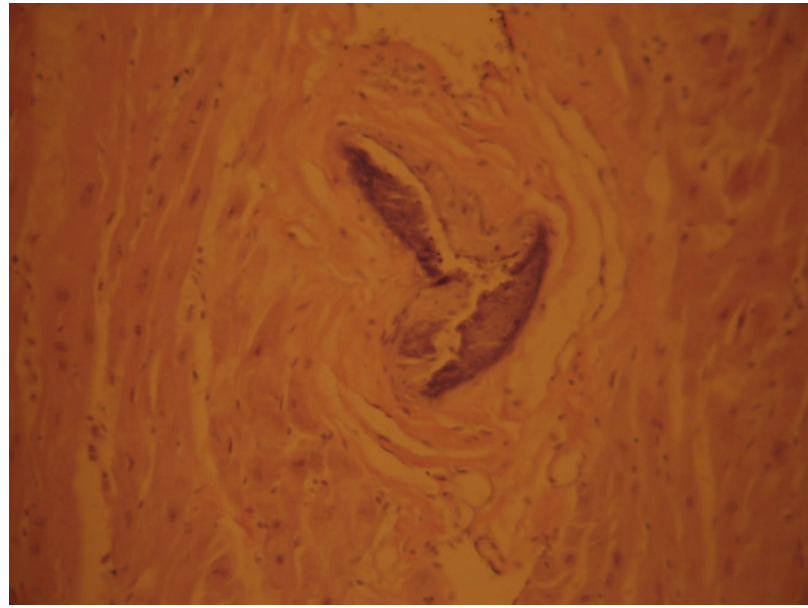

Figure 2

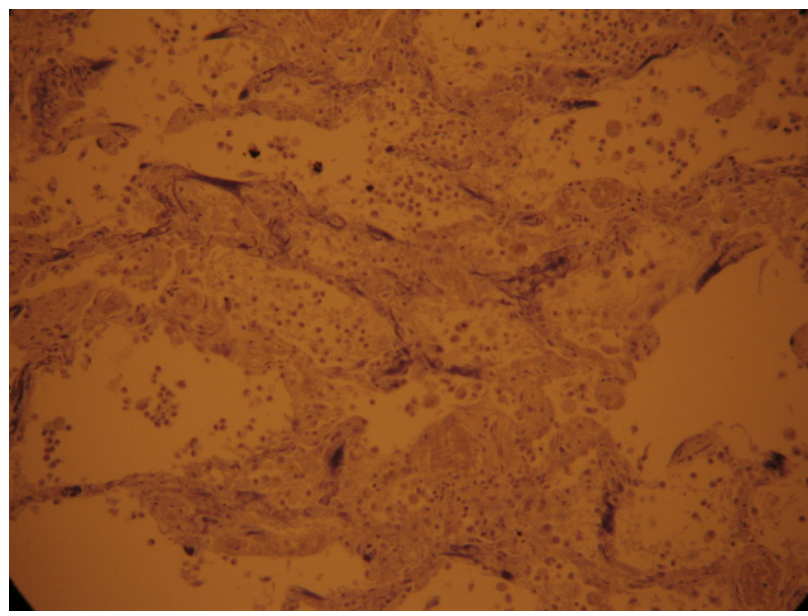

Figure 4

After autopsy it is concluded that the cause of death is myocardial infarction, which is the result of difficult and long-lasting atherosclerotic heart and blood vessels disease. Parathyroid adenoma significantly accelerated atherosclerotic alterations of blood vessels, which caused bleeding in plaque of left coronary artery, and deathly outcome.

\section{Discussion}

Patients with pHPT frequently have diseases and conditions associated with the disorder of calcium ion concentration in the body: renal dysfunction, nephrolithiasis, hematuria, osteoporosis and osteopenia, hypertension, gastric ulcers, pancreatitis. Some of the most frequent symptoms include: feebleness, weakness, exhaustion, polydipsia, polyuria, loss of appetite, nausea, depression, memory loss, pain in joints and bones ${ }^{7,8}$. PHPT diagnosis is most frequently determined by detecting high serum concentrations of calcium during routine laboratory analyses. Our patient served prison sentence, she didn't check her health condition, so we don't have data about previous health problems, and parathyroid adenoma was diagnosed postmortem.

Onadmission she felt pain in thechest, and supraventriculartachycardia was verified electrocardiographically. During hospitalization at Clinical Center Kragujevac, certain laboratory analyses were conducted, and calcium blood level was at the top part of reference value scale $(2.74$ and $2.62 \mathrm{mmol} / \mathrm{l})$. Patients with pHPT frequently have abnormal heart rhythm which is caused by hypercalcemia. It has been proved that moderate 
chronic hypercalcemia (mild to moderate hypercalcemia) induces morphological changes on cardiomyocytes which causes hypertrophy of the left ventricle, greater predisposition to atherosclerotic alterations as well as diastolic dysfunction $9-11$. Our patient was diagnosed with hypertrophy of the left ventricle postmortem, during autopsy, and due to irregular treatments, we don't have any data about eventual hypertension which could indicate the presence of high hypertrophy of the left ventricle. Coronary arteries showed signs of advanced atherosclerosis, with bleeding in atherosclerotic plaque. Hypertrophy of the left ventricle, right heart dilatation, and atherosclerotic alterations are explained by the presence of parathyroid adenoma, i.e. pHPT. It has also been confirmed that these patients, due to renin-angiotensin-aldosterone system disorder, more frequently have structural and functional damage of blood vessels' wall ${ }^{12,13}$. Our patient's alveolar basal membrane was calcified, which confirms long-lasting hypercalcemia.

Renal dysfunction caused by nephrolithiasis, as well as osteoporosis and osteopenia followed by bone mass loss are frequent in patients with pHPT and are associated with hypercalcemia ${ }^{2-4}$. Hedback and Oden conducted a research on 845 patients with pHPT, and showed that there was a connection between cardiovascular diseases and renal function deterioration in patients with $\mathrm{pHPT}^{14}$. Our patient's US of abdomen and urinary tract showed significant renal parenchyma damage and calculi on both sides which was confirmed during autopsy. Also, autopsy found signs of kidney damage caused by long-lasting, untreated hypertension.

It should be mentioned that $\mathrm{pHPT}$ can also appear in asymptomatic form with or without hypercalcemia or parathyroid, i.e. hypercalcemic crisis can develop, leading to dehydration, heart and renal function disorders, abdominal pain, ulcers, and nervous system functions disorder as well $19,15,16$. During admission our patient was disoriented, with an altered mental status, pale and dehydrated, which fits in with clinical pHPT signs, but she didn't have abdominal pain or ulcer. Due to a range of polymorphic neurological disorders and mental disturbances, sometimes these patients are characterized as psychiatric patients.

Clinical picture of patients with pHPT is diverse, and it mostly depends on calcemia as well as health conditions. Our patient had multiple dysfunctions: damage of cardiovascular system with supraventricular tachycardia, myocardium hypertrophyand advanced atherosclerotic alterations; renal dysfunction with calculi on both sides. It should be mentioned that the patient served prison sentence, so a lot of data about her earlier health condition are not available.

\section{Conclusion}

Parathyroid adenoma was not diagnosed earlier due to neglect and her lifestyle. The cause of death was myocardial infarction, and it was determined after completing forensic and clinical autopsy and pathohistological examination of organs. Parathyroid adenoma, i.e. primary hyperparathyroidism, significantly accelerated myocardium damage and atherosclerotic alterations of blood vessels, causing bleeding in plaque and deathly outcome.

\section{Literatura}

1. Bandeira L, Bilezikian J. Primary Hyperparathyroidism. F1000Res. 2016;4;5.

2. Neagoe RM, Sala DT, Borda A, Mogoanta CA, Muhlfay G. Clinicopathologic and therapeutic aspects of giant parathyroid adenomas - three case reports and short review of the literature. Rom J MorpholEmbryol 2014; 55(2):669-674.

3. Kiernan TJ, O’Flynn AM, McDermott JH, Kearney P. Primary hyperparathyroidism and the cardiovascular system. Int J Cardiol. 2006;18;113(3):E89-92.

4. Pepe J, Cipriani C, Sonato C, Raimo O, Biamonte F, Minisola S. MECHANISMS IN ENDOCRINOLOGY: Cardiovascular manifestations of primary hyperparathyroidism: a narrative review.Eur J Endocrinol.2017 Sep 1.pii: EJE-17-0485.

5. Walker MD, Rubin M, Silverberg SJ. Nontraditional manifestations of primary hyperparathyroidism.J ClinDensitom. 2013;16(1):40-7. 
6. Cheng YT, Su CS, Chang WC, Chiang MH, Ting CT, Lin WW. Hypercalcemia-Induced New Onset Left Bundle Branch Block Mimicking Acute Myocardial Infarction in a Patient with Primary Hyperparathyroidism. ActaCardiol Sin. 2013;29(2):188-91.

7. Elaraj DM, Clark OH. Current Status and Treatment of Primary Hyperparathyroidism. The Permanente Journal.2008;12(1):32-7.

8. Michels TC, Kelly KM. Parathyroid disorders. Am Fam Physician. 2013;15;88(4):249-57.

9. Brown TC, Healy JM, McDonald MJ, Hansson JH, Quinn CE. Heart block and acute kidney injury due to hyperparathyroidism-induced hypercalcemic crisis. Yale J Biol Med. 2014;12;87(4):563-7.

10. Ker J. The hyperparathyroid heart mimicking acute myocardial infarction.Cardiovasc J Afr. 2009;20(3):201-2.

11. 11.Hagstrom E, Ahlstrom T, Arnlov J, Larsson A, Melhus H, Hellman P, Lind L. Parathyroid hormone and calcium are independently associated with subclinical vascular disease in a community-based cohort.Atherosclerosis. 2015 Feb;238(2):420-6.

12. 12. YenerOzturk F, Erol S, Canat M M, Karatas S, Kuzu I, DoganCakir S, Altuntas Y. Patients with normocalcemicprimary hyperparathyroidism may have similar metabolic profile as hypercalcemic patients.Endocr J. 2016;63(2):111-8.

13. Loupy A, Ramakrishnan SK, Wootla B, Chambrey R, de la Faille R, Bourgeois S, Bruneval P, Mandet C, Christensen EI, Faure H, Cheval L, Laghmani K, Collet C, Eladari D, Dodd RH, Ruat M, Houillier P. PTH-independent regulation of blood calcium concentration by the calcium-sensing receptor.J Clin Invest. 2012 Sep;122(9):3355-67.

14. Hedback GM, Oden AS. Cardiovascular disease, hypertension, andrenal function in primary hyperparathyroidism. J Intern Med 2002; 251:476-83.

15. Madkhali T, Alhefdhi A, Chen H, Elfenbein D. Primary hyperparathyroidism. Ulus CerrahiDerg. 2016; 32(1): 58-66.

16. Blaine J, Chonchol M, Levi M. Renal control of calcium, phosphate, and magnesium homeostasis.Clin J Am SocNephrol. 2015 Jul 7;10(7):1257-72.

Corresponding author:

Živana Slović,

SvetozaraMarkovića 69, 34000 Kragujevac,

tel. $065 / 3890089$

e-mail: zivanaminic@yahoo.com 